УДК 821.161. 2.09 (Гусейнов)

Мельник Н. Г., кандидат філологічних наук, доцент, завідувач кафедри української та світової літератур ДВНЗ «Криворізький державний педагогічний університет»

\title{
ОСМИСЛЕННЯ КОНЦЕПТУ «ІСТОРІЯ» В РОМАНІ ГРИГОРІЯ ГУСЕЙНОВА «ПОВЕРНЕННЯ В ПОРТЛЕНД»
}

У статті розглядаються особливості відображення концепту «історія» в романі відомого письменника Григорія Гусейнова «Повернення в Портленд». Твір, щяо відноситься до зразків літератури нон-фікшн, презентує правдивий образ історичної доби 60-х років XX століття. Майстерність письменника, своєрідність авторського стилю, ширість, відвертість, уміння відтворити культурну атмосферу минулого, сприяють тому, щэо читач не лише абсолютно довіряє оповідачеві, а й природно співіснує з персонажами та часопросторовими координатами твору.

Роман «Повернення в Портленд» - гімн свободі людини, яка здатна ї̈ зберегти навіть у тоталітарному суспільстві, яким був Радянський Союз. 
Ключові слова: документальна література, роман у щзоденниках і листах, концепт «історія».

В статье рассматриваются особенности отображения конщепта «история» в романе известного писателя романе Григория Гусейнова «Возвращение в Портленд». Произведение, которое относится $\kappa$ образиам литературы нон-фикин, представляет правдивый образ исторической эпохи 60-х годов ХХ века. Мастерство писателя, своеобразие авторского стиля, искренность, откровенность, умение воспроизвести культурную атмосферу прошлого, способствуют тому, что читатель не только абсолютно доверяет рассказчику, но и естественно сосуществует с персонажами $u$ временно-пространственными координатами произведения.

Роман Григория Гусейнова «Возвращение в Портленд»- гимн свободе человека, который способен сохранить ее даже в тоталитарном обществе, каким был Советский Союз.

Ключевые слова: документальная литература, роман в дневниках и письмах, кониелт «история».

This article focuses on the peculiarities of reflecting the "history" concept in the novel by famous writer Grygoriy Huseynov "Return to Portland". This work is related to non-fiction literature samples and represents a true image of the 60ies period in the 20ieth century. The writer's mastership, the author's style originality, openness, frankness and recreating the past cultural atmosphere contribute to the fact that the reader not only completely trusts the narrator, but also naturally coexists with the characters and time and space coordinates of the work.

The novel "Return to Portland" is the anthem to human freedom that can be saved even in a totalitarian society, which was the Soviet Union.

Key words: documentary literature, novel in diaries and letters, concept "history".

Розвиток української літератури останніх десятиліть свідчить про ii творче оновлення. Сьогодні літературний процес - це не лише калейдоскоп відомих та нових імен, це, перш за все, творчий експеримент, пошук шляхів до сучасного розуміння значення літератури в житті людини, змісту i форми художнього твору, ролі письменника в суспільстві. Саме тому сучасна українська література відзначається жанровою різноманітністю, ідейною багатогранністю.

Кінець XX - початок XXI століття ознаменувався стрімким зростанням інтересу до так званої документалістики, пророкуючи ій першорядне місце у культурному просторі в найближчому майбутньому. Сучасні дослідники, вивчаючи феномен документалістики в літературі, часто поруч використовують такі терміни як «документалістика», «фактографія», «література факту» або «література nonfiction».

Нон-фікшн - це особливий літературний жанр документальної прози. Він будується на реальних подіях, без домислів. Однак, факти подаються через 
образне креативно-абстрактне сприйняття автора. Цей жанр ще можна назвати документальною публіцистикою життя.

Документальна література, нон-фікшн (англ. Non-fiction) - особливий літературний жанр, для якого на відміну художній літературі характерна побудова сюжетної лінії виключно на реальних подіях. Документальну літературу ще називають документалістикою, документальною прозою, літературою факту.

Як правило, документальна література заснована на спогадах очевидців, документах. Також можуть використовуватися спогади самого автора. При цьому авторська точка зору проявляється у відборі та структуруванні матеріалу, а також в оцінці подій. У документальній прозі широко використовується публіцистичний стиль.

Українська літературна енциклопедія пропонує таке визначення: «Документальна література, документалістика - твори художньопубліцистичних, науково-художніх $i$ художньо-документальних жанрів, в основу яких покладено документальні матеріали, подані повністю або частково чи відтворені у вигляді вільного викладу» [Літературознавча енциклопедія 2007].

Сучасний дослідник документальної літератури О. Галич визначає «документалістику, як літературу, щзо базується на реальних історичних документах $і$ фактах $і$ охоплює три найважливіших напрямки: мемуаристику, художню біографію та художню публіцистику. Важливою ознакою такої літератури є авторське осмислення певних суспільно-історичних подій чи життєвого шляху реальної історичної особи, або важливої для життя народу проблеми, здійснене за законами художньої творчості із залученням справжніх документівсвого часу, глибоким співвіднесенням власного духовного досвіду автора із внутрішнім світом героїв, соціальною й психологічною природою їхніхучинків» [Галич 2003:20].

Особливого розквіту non-fiction набуває на межі XX-XXI ст. Л. Рошаль пов’ язує це з «постійним розвитком історичного мислення широкого загалу та 
ӥх зростаючим інтересом до достовірних подій, які відбуваються в дійсності. Викликане значними політичними ци сочіальними потрясіннями намого століття бажсання людей осмислити сучасність як певний відрізок історії, зрозуміти сьогодення як частину загального історичного процесу визначає суспільну заиікавленість мистеитвом, побудованим на достовірних фактах» [Галич 2003:14]. Американець Б. Ніколз у своїй книзі «Вступ до документалістики» звертає увагу на те, що документалістика, пропонуючи новий погляд на звичайне життя, спонукає переосмислити й проаналізувати його.

Про так званий «занепад метанарацій» писав Ж.-Ф. Ліотар у роботі «Ситуація постмодерну». «Метанарації» («великі наративи» або «великі розповіді»), що оформлюються в конкретній традиції i становлять, за Ж. Ліотаром, соціокультурні домінанти, які задають семантичну рамку будь-яких наративних практик у контексті культури, характерні для епохи модерна, і переживають кризу в наші часи. Постмодерн відмовляється від ілюзорної можливості цілісно виразити сутність буття і натомість, шукаючи засоби відображення різних його відтінків, відштовхує метанарації, замінюючи ïх різноманітним «фрагментарним досвідом». Так, «великі наративи» розпадаються на окремі локальні історії, жодна 3 яких не претендує на пріоритетність. Відбувається це, на думку Ж.-Ф. Ліотара, через кризу цінностей та ідеалів, викликаних стрімким розвитком науки: «Спрощуючи до крайнощів, ми вважаємо «постмодерном» недовіру по відношенню до метарозповідей. Вона $\epsilon$, звичайно, результатом прогресу науки; але й прогрес у свою чергу має на увазі недовіру. 3 виходом 3 використанням етанаративного механізму легітимації пов'язана, зокрема, криза метафізичної філософії, а також криза залежної від неї університетської інституції. Наративна функція втрачає свої функтори: великого героя, великі небезпеки, великі кругосвітні плавання й велику мету». Недовіра науки до метанаративів, викликанатим, що «за іiі власними критеріями» за більшістю 3 великих розповідей «ховається вигадка» [Варикаша 2010]. Так, підвищується цінність особистого досвіду одного 
людського життя, отже, сам специфічний спосіб світосприйняття, світовідчуття, оцінки пізнавальних можливостей людини, iї місця, ролі в суспільстві та світі загалом, характерний для нашої епохи, тяжіє до есеїстичної оповіді, 3 поясненнями й осмисленнями.

Особливе місце в культурі сьогодення займає документальна література (нон-фікшн). Це масив літературних творів, які грунтуються на реальних подіях, а тому викликають у читача особливу довіру. Тому для аналізу ми обрали роман сучасного криворізького письменника Григорія Гусейнова «Повернення в Портленд».

Григорій Гусейнов - знаний український письменник, великий майстер документально-художніх книг, головний редактор журналу «Кур’єр Кривбасу», автор книг «Незаймані сніги» (1993), «Чаша ювеліра Карла Феберже» (1995), «Станційні пасторалі» (1999, 2005), «Незаймані сніги» (2010), десяти книг «Господні зерна» (2000-2005), лауреат премій імені Івана Огієнка «Благовіст», імені Володимира Ястребова, Фундації Антоновичів, імені Володимира Винниченка, імені Валер'яна Підмогильного, імені Василя Стуса, лауреат Національної премії України імені Т. Шевченка, премії Ліги українських меценатів ім. С. Чикаленка, член Національної спілки письменників України, фундатор унікальної мистецької премії «Глодоський скарб».

Сьогодні Григорій Гусейнов - один із найвідоміших представників літератури non-fiction, а його роман «Повернення в Портленд» - яскрава іï ілюстрація.

«Повернення в Портленд» - роман у листах (епістолярний роман). Це різновид роману, що є циклом листів одного чи кількох героїв. У таких листах, як правило, виражені душевні переживання героїв, висвітлена їх внутрішня еволюція.

Загалом жанрову своєрідність твору визначити досить непросто, бо маємо справу 3 синкретичним поєднанням різних форм роману. Складний i багатогранний зміст, різновимірність позицій автора та персонажів твору 
диктують і складність його побудови, що поєднує в собі риси епістолярного, історичного, психологічного та філософського романів.

Твору притаманна підкреслена деталізація подій, коли факти, що наводяться, автор намагається відтворити максимально точно. Також характерним $\epsilon$ застосування письменником стильових рис «потоку свідомості»- техніки письма, коли думки викладаються не за якоюсь особливою логікою, а довільно, так, як диктує авторське внутрішнє відчуття.

I деталізація, i «потік свідомості» у творі досить функціональні: простежується певний концептуальний підхід автора до художнього відображення реальності, адже все в житті людини важливе, кожна думка, почуття, подія. А тому їх необхідно відтворити якомога точніше. 3 іншого боку, саме завдяки цій деталізації створюється образ часу, історична аура доби, про яку йдеться. Читач ніби поринає у минуле, стаючи такою реальною діючою особою 60-х років ХХ ст., як і герої твору.

Григорій Клочек, характеризуючи провідні особливості творчості Григорія Гусейнова зазначає: «Думати, що література факту, т.зв. non-fiction власне в художньому плані позначена (у порівнянні з белетристикою) якоюсь другорядністю, і що ця другорядність є іï мало чи не природною ознакою, це думати «по-радянському» <..> Вже пора визнати, що «Господні зерна» продемонстрували новаторську поетику не лише в українській non-fiction. Відомий усім «потік свідомості» Григорій Гусейнов трансформував на зовсім інший рівень, про який можна говорити, як про вільне, нібито нічим не обмежене плетення павутини з фактів. Насправді ж таке плетення павутини при усій своїй, здавалося б, стихійності, яка іноді може нагадувати «броунів рух» думки, насправді $є$ високоорганізованим, добре продуманим прийомом, 3 допомогою якого письменник отримував змогу підбирати різні факти, що організовувалися в цілісність під впливом потужного силового поля, зарядженого однією смисловою інтенційністю. «Повернення в Портленд», жанр якого визначений автором як «роман у щоденниках і листах», імітує non-fiction. Гусейнов ніколи не був чистим белетристом, і вже ніколи ним не стане - він 
надто добре знає силу факту, до того ж володіє довершеним умінням iі охудожнювати» [Клочек 2012].

Автор активно використовує прийом «потоку свідомості», що змушує читача уповні довіряти прочитаному: «<..> київські вулищі 1960 років - клекіт, торохкотіння та деренчання, зелені двори з розвіманою по периметру білизною, сараями та голубами, колонкою та обов'язковою калюжею в центрі. А щуе запах смажених пиріжків станційної лоточниці, трамваї, схожі на вусатих дядьків (темно-сині та яскраво-червоні внизу, та світло-кремові вгорі), вранці двірники зі илангами в руках, підворіття, кам'яні сходи, якими легко можна обійти все місто, «український хліб», насіння в баби біля Центрального стадіону, занедбана до потворності брама Заборовського, столітні каштани з Володимирської вулищі, колишня артіль глухонімих, швейна фабрика імені Горького [...], бельведер 3 видом на Дніпро на місиі старовинного променаду, «Київський торт»; він тоді випікався в столітніх закопчених печах, а їх берегли як найбільшу цінність - у всіх інших печах торт втрачав свій смак» [Гусейнов 2011:63].

У романі ми зустрічаємо старі назви вулиць, кав’ярень, кінотеатрів 40-річної давнини. Так сучасний читач переноситься в минуле і стає активним учасником подій.

Художні підходи автора, визначені Григорієм Клочеком як «східний погляд», свідчать про бачення за начебто дрібними, побутовими, другорядними речами глибокий філософський зміст. Так із маленьких шматочків (як у калейдоскопі) складається «матриця» внутрішнього світу людини «радянських» часів, людини, яка і сьогодні живе поряд із нами і відіграє важливу роль у житті нашого суспільства.

У одному 3 інтерв’ю Оксана Забужко, говорячи про книгу «Чорнобильська молитва» Світлани Алексієвич, лауреатки Нобелівської премії, говорить: «...ви просто не знаєте, що таке література! Так, це нон-фікшн, але там головне не те, як воно написано, якою мовою, і навіть не історії іiї героїв, такого справді в світовій літературі понаписувано донесхочу, це ще «на Нобеля 
не тягне», як кажуть наші сноби... А головне там - монтаж, принцип монтажу: оце є абсолютно інноваційна штука з літературної точки зору! Вона вибудовує космос, викладає ... із тих почутих історій, як із шматочків смальти ... секретики викладає, аплікацію. I 3 усіх цих інтерв’ю, голосів, які вона оркеструє, врешті-решт викладає практично гомерівський епос» [Забужко 2013]. Цей вислів О. Забужко про «техніку» написання творів ми використали тому, що в ньому, на нашу думку, аргументовано прийоми побудови тексту з маленьких епізодів, спогадів, листів. Це механізм творення так званої «ілюзії історичного часу». Його застосовує в своєму романі i Григорій Гусейнов.

Окремо хочеться звернути увагу на художні функції назви роману. У ній звучить алюзія на пісню Б. Окуджави «Піратська лірична»:

Когда воротимся мы в Портленд,

Ей Богу я во всем покаюсь.

Да только в Портленд воротиться

Нам не придется никогда.

Когда воротимся мы в Портленд,

Клянусь, я сам взбегу на плаху,

Да только в Портленд воротиться

Нам не придется никогда.

Когда воротимся мы в Портленд,

Нас примет Родина в объятья

Да только в Портленд воротиться

Не дай нам, Боже, никогда [Гусейнов 2011].

Із топонімом «Портленд» ми зустрічаємося ще на початку твору: «Микола <..> свідомо вибрав Красноярський край. Йому хотілося вирушити кудись далеко, на край світу, щуоб ніколи вже не повертатися в своє рідне Городище, в Київ (ми всі часто називали його Портлендом, згадуючи пісню популярного барда), хоча ие зовсім інша історія» [Гусейнов 2011:12]. 
Протягом роману лейтмотив пісні визначає ключові моменти осмислення персонажами власної сутності, самих себе:

1) «<...> не особливо весело було й Славі. Він раптом ні з того ні з сього затіяв о другій годині ночі в коридорі концерт; звідкись приніс гітару й став мене примушувати: "Давай піратську». Я відмовлявся, однак тоді голосно став співати він: «Когда воротимся мы в Портленд, ей-богу, я во всем покаюсь...» Потім сказав: «Інавіщзо я, дурень, залишався?» [Гусейнов 2011:176];

2) «Ось уже й рік минув. Останній, щзо живу в Жулянах на ПортлендіКиєві. «Пусть будет крепок ром ямайский, все остальное-ерунда». В липні наступного ми всі роз’їемося. Отримавши дипломи, будемо веселитися, пиячити. А потім влаштовуватися, проштовхуватися на посади. В нас будуть родини. Й так триватиме дуже довго, поки ми враз постаріємо. Схаменемося $i$ станемо раптом роззиратися: a далі? Навіщуо жили?» [Гусейнов 2011:322].

Слід зазначити, що творчість Булата Окуджави в радянські часи відігравала особливу роль. Це був своєрідний вияв протесту проти тиску тоталітарної системи на особистість. Позбавлені ідеологічних штампів, твори Булата Окуджави торкалися «вічних» проблем буття людини, повертаючи іiі до традиційних неперехідних цінностей. Вірші, покладені на музику, виконувані автором у своєрідній довірливій манері, часто приховували іронічний погляд автора - людини-інтелектуала, що перебуває поза межами «комуністичних» ідеалів, добре розуміє, що відбувається і не бажає втрачати «людське»у собі на догоду системі. Його твори слухали, збираючись у товаристві близьких за духом людей, яким можна довіряти (бо практика доносів, стукацтва, боротьби 3 «ворогами» комунізму ще тривала), напівтаємно. У творах Булата Окуджави тонко, інтелігентно було розставлено необхідні акценти, що дозволяло людині навіть у тоталітарній державі залишатися людиною.

Григорій Клочек справедливо зазначає: «Пісня Булата Окуджави «Піратська лірична», цитації 3 якої лейтмотивом проходять крізь твір. 
Літературознавець Дмитро Дроздовський, так трактує символічне значення Портленду: «Портленд - ие якийсь міф пам'яті, простір, у який нібито найбільше хочеться повернутися. Але разом із тим повернення в Портленд означатиме смерть, зупинку. Повернення в Портленд має залишитися нездоланним вояжем, нездійсненним міфом. Портленд - ие ілюзія, що наповнює життя сенсом; у кожної людини має бути така ілюзія з минулого, згадуючи яку, оживаєш внутрішньо...» [Клочек 2012].

Григорій Клочек так розуміє художню функцію назви: «У контексті роману (а він в основному визначає «опцію сприймання» цих слів) «Портленд» розуміється не тільки як місто, що викликає у героїв ностальгічну тугу за кількома молодими роками, що проминули в ньому, - такої туги фактично немає, бо художній світ, побудований на непривабливому фактажі і сповнений ледь відчутного настрою неприкаяності, яка завжди супроводжує людську чи суспільну (національну) нереалізованість. Іншими словами, той «золотий гомін», який стояв над Києвом у щасливий час національного відродження 1918 року і який почув своїм абсолютно музичним слухом Павло Тичина, він, Микола Волошин, який теж був обдарований ідеальним слухом, уже не чув він просто вже не звучав ні над Києвом, ні над Україною, і тому його вже не вловлював найбільш чутливий слух. Ще кілька років назад, на початку 60 -х, той золотий гомін, який супроводжує ледь відчутні вольові зусилля до національного відродження, ще можна було почути. Він зазвучить і пізніше, в кінці 80-х-початку 90-х. Особливо обнадійливо він звучатиме у 2004 році. Але швидко затихне» [Клочек 2012].

Iз тексту пісні стає зрозуміло: якщо пірати повернуться в Портленд (начебто, бажане місце), вони змушені будуть стати іншими, занадто «правильними», такими, як їх хоче бачити суспільство. Для цього необхідно перекреслити все минуле життя. Пісня, яка лягла в основу назви роману, закінчується словами: «Да только в Портленд воротиться не дай нам, Боже, никогда!». Отже, не да нам, Боже, змінитися, стати такими, як усі, зрадити власному «Я», загубити свій авантюризм, зректися бажань пригод і почати 
жити буденним звичайним життям. Цього ні автор для своїх героїв, ні герої не хочуть.

Твір побудовано на глибинному внутрішньому протиріччі, притаманному людській душі загалом: 3 одного боку в романі постійно звучить ностальгія за Портлендом (Києвом 60-х років), за молодістю, що минула, максималізмом, авантюризмом, притаманним молодій людині, відчуттям того, що можна досягти будь-якої мети; з іншого - лейтмотив пісні, яка лягла в основу назви, диктує: не треба повернення в часи, коли все життя було контрольоване радянською ідеологією, не було тієї життєвої мудрості, котра є зараз.

Якщо відштовхуватися від назви твору, то його ідею можна визначити так: це утвердження творчого начала в людині, іiі вміння бачити велике в малому, самоцінності кожної особистості, захоплення красою і глибиною душі «звичайної» людини.

Отже, роман «Повернення в Портленд» - гімн свободі людини, яка здатна iï зберегти навіть у тоталітарному суспільстві, яким був Радянський Союз.

У творі звучать роздуми письменника про те, як просто можна втратити бажання відкривати щось нове, творити, радіти життю, якщо поринеш у буденність. Нереалізовність Миколи в родинному і суспільному життіпровідний мотив твору.

Так звичайна людська історія стає для читача близькою. Він разом із автором співпереживає героям твору, стає учасником подій i, звичайно, довіряє написаному як людина-свідок того, що відбувається. За такими простими історіями - доля людини, iii сутність, що складається 3 правильних i неправильних учинків, сумнівів, помилок. Але вона не менш цікава, ніж пригодницький твір, бо розкриває глибинні психологічні витоки діяльності людини.

Отже, твір презентує правдивий образ історичної доби 60-х років XX століття. Майстерність письменника, своєрідність авторського стилю, ширість, відвертість, уміння відтворити культурну атмосферу минулого, сприяють тому, 
що читач не лише абсолютно довіряє оповідачеві, а й природно співіснує 3 персонажами та часо-просторовими координатами твору.

\section{БІБЛІОГРАФІЯ}

Варикаша 2010 - Варикаша М. М. Література non-fiction: поміж фактом і фікцією [Електронний ресурс] / М. М. Варикаша // Актуальні проблеми слов'янської філології. - 2010. - Випуск XXIII. - Частина 3. - Режим доступу: http://dspace.nbuv.gov.ua/bitstream/handle/123456789/38201/03-Varykas ha.pdf?sequence $=1$.

Галич 2003 - Галич О. Жанрова система документальної літератури / Олександр Галич // Документалістика на порозі XXI століття : проблеми теорії та історії : матеріали Всеукраїнської наукової конференції, [м. Луганськ, 18-19 вересня 2003 р.] - Луганськ : Знання, 2003. - С. 19-36.

Галич 2008 - Галич О. А. У вимірах non-fiction : щоденники українських письменників XX століття : монографія / Олександр Галич. - Луганськ : Знання, 2008. - 200 c.

Гусейнов 2011 - Гусейнов Г. Повернення в Портленд: роман у щоденниках і листах / Григорій Гусейнов. - К. : Ярославів Вал, 2011. - 368 с.

Забужко 2013 - Забужко О. : «Письменник завжди самотній, за визначенням, бо його завдання - витворити свій власний світ» [інтерв'ю] [Електронний ресурс] / О. Забужко // Культура, 23 квітня 2013. - Режим доступу до журн. : http://lb.ua/culture/2016/04/23/333434_oksana_zabuzhko_pismennik_ zavzhdi.html.

Клочек 2012 - Клочек Г. Музика підтекстових смислів (Про новий роман Григорія Гусейнова «Повернення в Портленд») [Електронний ресурс]/ Григорій Клочек // Літературна Україна, 2012. - № 15 (12 квіт.) - Режим доступу: http://litukraina.kiev.ua/morints.

Літературознавча енциклопедія 2007 - Літературознавча енциклопедія: У двох томах. Т. 1. / [авт.-уклад. Ю. І. Ковалів]. - К. : ВЦ «Академія», 2007. $608 \mathrm{c}$.

http://bo0k.net/index.php?p=achapter\&bid=10055\&chapter $=1$

https://uk.wikipedia.org/wiki 